\title{
Diet-induced developmental plasticity in life histories and energy metabolism in a beetle
}

\author{
La dieta induce plasticidad del desarrollo en los rasgos de historia de vida y \\ metabolismo energético en un escarabajo
}

\author{
SERGIO URREJOLA ${ }^{1}$, ROBERTO NESPOLO ${ }^{2} \&$ MARCO A. LARDIES ${ }^{1}$, * \\ ${ }^{1}$ Departamento de Ciencias, Facultad de Artes Liberales \& Facultad de Ingeniería y Ciencias, \\ Universidad Adolfo Ibáñez, Diagonal Las Torres 2640, Peñalolén, Santiago, Chile \\ ${ }^{2}$ Instituto de Ciencias Ambientales y Evolutivas, Facultad de Ciencias, Universidad Austral de Chile, Casilla 576, Valdivia, Chile \\ *Corresponding author: marco.lardies@uai.cl
}

\begin{abstract}
Adaptive phenotypic plasticity, has been recognized as an important strategy by which organisms maximize fitness in variable environments, which vary through development. A disassociation among stages should represent a null effect of the environment experienced during early ontogeny in the expression of adult traits. Food quality greatly influences survival, development and reproduction in many arthropod herbivores. We examined the effects of diet protein in physiological and life-history traits in the yellow mealworm beetle Tenebrio molitor through ontogeny. We established four experimental treatments: Low Protein (LP), Low Protein Control (LPC), High Protein (HP), and High Protein Control (HPC) with recently eclosioned larvae each. Individuals were maintained on the same diet or transferred to the opposite diet for all pupae period and almost all adult period. Contrary to the expected, the duration of life-cycle, larval growth rate and body mass in T. molitor were similar in diet treatments. We found intra-individual trade-offs between environmental diet (rich or poor in protein content) during larval phase and egg number. Larvae fed on a protein-deficient diet exhibited significantly higher respiratory rates than larvae fed on a rich protein diet. Compensatory feeding could act in T. molitor larvae indicating differences in metabolism but not in growth rate, body mass and life-cycle characteristics. Our results demonstrate the plasticity of reproductive and metabolic traits and lifecycle characteristics of $T$. molitor and how changes that occur in relation to diet can have profound effects on progeny and female fitness.
\end{abstract}

Key words: $\mathrm{CO}_{2}$ production, complex life-cycle, food quality, metabolism, ontogeny.

\section{RESUMEN}

La plasticidad fenotípica adaptativa ha sido reconocida como una estrategia importante por el cual los organismos maximizan su adecuación biológica en ambientes variables y la cual varía a lo largo del desarrollo. En los organismos la plasticidad fenotípica generalmente se refiere a como los diferentes tipos de rasgos pueden estar conectados con una relación alométrica, la cual varía a lo largo del desarrollo. Una disociación entre los distintos estadios ontogenéticos debiese representar un nulo efecto del ambiente experimentado durante la ontogenia temprana en la expresión de los rasgos de los individuos adultos. La calidad del alimento influencia la sobrevivencia, desarrollo y reproducción en la mayoría de los artrópodos herbívoros. En este estudio examinamos los efectos de la cantidad de proteína en la dieta sobre los rasgos fisiológicos y de historia de vida en el escarabajo Tenebrio molitor a través de toda la ontogenia. Con larvas recién eclosionadas se establecieron cuatro tratamientos experimentales: Baja Proteína (LP), Control Baja Proteína (LPC), Alta Proteína (HP) y Control Alta Proteína (HPC). Los individuos fueron mantenidos en la misma dieta o transferidos a la dieta opuesta en el estadio de pupa y mantenidos durante todo el periodo de adulto. Contrario a lo esperado, la duración del ciclo de vida, tasa de crecimiento larval y masa corporal en T. molitor fue similar entre los distintos tratamientos. Además, se econtraron compromisos individuales entre la dieta ambiental (contenido rico o pobre de proteína) durante la fase larval y el número de huevos de hembras adultas. Las larvas alimentadas en una dieta con deficiencia en proteína exhibieron una tasa respiratoria significativamente mayor que larvas alimentadas en una dieta rica en proteínas. La alimentación compensatoria podría estar actuando en las larvas de T. molitor indicando diferencias en el metabolismo pero no en la tasa de crecimiento, masa corporal y las características del ciclo de vida. Nuestros resultados demuestran plasticidad fenotípica de los rasgos metabólicos y de historia de vida en T. molitor y cómo esta cambia en relación a la dieta y cómo estos cambios pueden tener efectos significativos sobre la adecuación biológica de la progenie y de la hembra.

Palabras clave: calidad del alimento, ciclo de vida complejo, metabolismo, ontogenia, producción de $\mathrm{CO}_{2}$. 


\section{INTRODUCTION}

Adaptive phenotypic plasticity, the environmentally induced phenotypic change, has been recognized as an important strategy by which organisms maximize fitness in variable environments (Bouvet et al. 2005, Pigliucci 2005). Phenotypic plasticity generally refers to different traits, that could be connected with an allometric relationship, which vary along the individual's development (Schlichting \& Pigliucci 1998).

Virtually, hundreds of studies have been published characterizing adaptive phenotypic plasticity in plants and animals, changing the way of thinking about how evolution works at the population and organismal level (see Via et al. 1995, De Witt et al. 1998, Pigliucci 2007). However, the role that early environment plays in determining the adult phenotype and performance, also known as developmental plasticity, have been less explored (Hoffmann 1999, Diggle 2002, Castañeda et al. 2010a).

Insects are animals with a wealth variety in complex life cycles, especially among the coleoptera order. One of the explanations of abundance and persistence of complex life cycles in animals, is that they present adaptive mechanisms to face variable and unpredictable environments depending on the developmental stage (Moran 1994, Boggs 2009). According to the "Beneficial Acclimation Hypothesis" (BAH), individuals acclimatized to a given environment might perform better in that environment compared with individuals acclimatized to a different environment (Leroi et al. 1994, Wilson 2002). However, tests of BAH have been attempted only in bacterial species or invertebrates with simple life cycles or within the same ontogenetic stage (Woods 1999, Woods \& Chamberlin 1999, Woods \& Harrison 2001, Lardies et al. 2004). In general, these studies have not supported the BAH but what these rejections imply about the adaptive value of physiological change remains unclear.

In addition, the allocation principle (Cody 1966, De Jong 1992, Kozlowski 1992) indicates that in a changing world where energy is limited, organisms will allocate resources in an optimal way, hence diverting energy and nutrients in paralell to vital functions such as growth, reproduction, movement and maintenance. For example, a number of authros have found that resource constraints during ontogeny play pivotal roles in the response to temporal variation in several selective factor in adults, such as predation risk, physiological performance and dispersion capacity (Greene 1989, Castañeda et al. 2006, Hoverman \& Relyea 2007).

Food quality greatly influences survival, development and reproduction in animals (Karowe \& Martin 1989, Yang \& Joern 1994, Rotem et al. 2003, Castañeda et al. 2010b). Also, different species of plants have been shown to vary greatly in their suitability and availability as a herbivore food source, as there are different populations of plants from the same species (Stockhoff 1993, Awmack \& Leather 2002, Castañeda et al. 2010a). This variation depends on geographical and/or seasonal factors, and may also depend on the stage of the plant's development or its physiological state, which may also fluctuate in space and time (Schultz et al. 1982, Stockhoff 1993, Alonso \& Herrera 2000). Phytophagous insects, such as coleopterans of the Tenebrionidae family, feed primarily on live vegetal material and fungi, some of them feed on stored grains (Cotton 1927), hence being a postharvest pest (FAO 1992).

In this study we examined the effects of diet protein in physiological and life-history traits in the yellow mealworm beetle Tenebrio molitor Linnaeus (Polyphaga, Tenebrionidae), which is an ectotherm with a complex life cycle and a cosmopolitan pest of stored grains (responsible of 10-50 \% losses of world grain production, FAO 1992) that can be easily reared in the laboratory (Worden \& Parker 2001).

\section{METHODS}

Animals, maintenance and culture

The common yellow mealworm beetle, Tenebrio molitor Linnaeus (Coleoptera, Tenebrionidae), is a widespread distributed species that is found throughout Chile (Vidal \& Guerrero 2007). We obtained T. molitor from a laboratory colony managed at the P. Universidad Catolica de Chile, Santiago. Beetles were housed in plastic cages containing a paper shelter and ad libitum water and food (bram and wheat middlings). The cages were maintained at room temperature $\left(20-22^{\circ} \mathrm{C}\right)$.

We obtained about 300 adults from a colony that was transported and maintained in our laboratory. Adults were allowed to mate and then females were separated into petri dishes. Individuals (eggs) were separated and after hatching, larvae were placed individually on 6 -well plates, diets were provided ad libitum. Individuals were maintained in an experimental chamber and 
rearing temperature and photoperiod were $18 \pm 1{ }^{\circ} \mathrm{C}$ and 12L:12D respectively. During larval period, body masses of individuals $(\mathrm{mb})$ were weighed every 14 days (starting on the $21^{\text {st }}$ day of life), during pupal period and 10 days after, and during adult period, every 10 days using an analytical balance with a precision of $\pm 0.01 \mathrm{mg}$ (ADAM AFA-180 LC). Larvae were reared from hatching to pupae on either a high-or low-protein diet (the "rearing diet", see Table 1). Pupae of one or two days were maintained on the same diet (controls) or transferred to the opposite diet (the "test diet") for all pupae period and almost all adult period prior to the measurements of the physiological and life-history traits. Thus we established four experimental treatments: A) Low Protein (LP), B) Low Protein Control (LPC), C) High Protein (HP), and D) High Protein Control (HPC) with 40 recently eclosioned larvae each.

The composition of the diets included ingredients listed in Martin \& Hare (1942) who described the nutritive requirements for Tenebrio molitor larvae to obtain the optimum growth rates (see Table 1). Total protein (\%) in the two different diets were $25.25 \%$ for the high protein diet (from here HP) and $10.25 \%$ for the low protein diet (from here LP). Diets were composed of the same ingredients but at different percentages, and they were also isocalorific (see Table 1).

\section{Life-history traits}

Relative Growth Rate (RGR) (van Emden 1969) was calculated using the periodical weights of larvae using the equation: $R G R=\left[\ln \left(\mathrm{mb}_{\mathrm{t} 1}\right)-\ln \left(\mathrm{mb}_{\mathrm{t} 0}\right) \mathrm{T}^{-1}\right]$; where $\mathrm{mbt}_{0}$ is the body mass $(\mathrm{mg})$ at the start of time interval, $\mathrm{mbt}_{1}$ is the body mass at the end of the time interval, and T is the number of days between the start $\left(t_{0}\right)$ and final $\left(t_{1}\right)$. We determined larval growth rate (LGR) in intervals during life cycle and adult growth rate (AGR).

After sexing experimental individuals following Bhattacharya et al. (1970), females were bred for five days to external males randomly chosen (obtained from our adult colony), then eggs were recollected after 15 days, and preserved in $70 \%$ ethanol. All eggs were counted and measured under a stereomicroscope with ocular micrometric calibration (in mm, Olympus SZX1 stereomicroscope).

\section{TABLE 1}

Composition of experimental high and low protein diets. Values are mean $\pm(\mathrm{SE})$.

Composición de las dietas experimentales alta y baja en proteínas. Valores mostrados son media $\pm(\mathrm{EE})$.

\begin{tabular}{lcc}
\hline Ingredients & High protein & Low protein \\
\hline Wheat flour (\%) & 2.00 & 5.20 \\
Brewer yeast (\%) & 20.25 & 2.25 \\
Wheat middlings (\%) & 3.00 & 3.00 \\
Moisture (\%) & 7.60 & 6.10 \\
Gross energy (Kcal) & $352.50 \pm 15.42$ & $345.30 \pm 18.08$ \\
\hline
\end{tabular}

\section{Metabolism}

To estimate the rate of metabolism of experimental individuals, we measured $\mathrm{CO}_{2}$ production through respirometry. The respirometry system used was similar to that described by Nespolo et al. (2007). $\mathrm{CO}_{2}$ production was measured continuously using an infrared $\mathrm{CO}_{2}$ analyzer (LI-COR LI6262, Lincon, NV, USA) capable of resolving differences of $1 \mathrm{ppm}$ of $\mathrm{CO}_{2}$ in air. The analyzer was calibrated periodically against a precision gas mixture. Baseline measurements taken before and after each recording we performed. Flow rates of dry $\mathrm{CO}_{2}$-free air (ambient air scrubbed free of water vapour and $\mathrm{CO}_{2}$ using a Drierite/soda lime

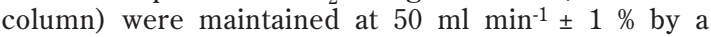
Sierra mass flow controller (Henderson, NV, USA). Metabolic chamber used was of $25 \mathrm{ml}$, each record was automatically transformed by a macro program recorded in the Datacan software (Sable Systems), in order to (1) correct the six-second lag introduced by the distance between the analyzer and the chamber and then to match the activity record with the $\mathrm{CO}_{2}$ record, and (2) to transform the measure from parts per-million to $\mathrm{ml}-\mathrm{CO}_{2}$ per hour, taking into account the flow rate. For this, we used the standard equation when flowmeter is downstream and $\mathrm{CO}_{2}$ is scrubbed prior to flow measurement: $\mathrm{CO}_{2}=\mathrm{STP}\left(\mathrm{FeCO}_{2}-\mathrm{FiCO}_{2}\right) \mathrm{FR}\left(1-\mathrm{FeCO}_{2}\right.$ $\left.+\mathrm{FiCO}_{2} / \mathrm{RQ}\right)^{-1}$, where STP $=$ standard temperature and pressure correction (equal to one with mass-flow controllers), $\mathrm{FeCO}_{2}=$ excurrent fractional concentration of $\mathrm{CO}_{2}, \mathrm{FiCO}_{2}=$ incurrent fractional concentration of $\mathrm{CO}_{2}, \mathrm{FR}=$ flow rate, $\mathrm{RQ}=$ respiratory quotient for herbivorous animals. Each individual was measured over a 25 min period (excluding the 5 min baseline mentioned above) and the chambers were not uncovered for visual monitoring, therefore we determined resting metabolism. Temperature during recording times was $20{ }^{\circ} \mathrm{C} \pm 2$.

\section{Statistical analysis}

To compare the duration of entire life-cycle, number of days of the different ontogenetic stages and the growth rate of different stages an one-way ANOVA was utilised with protein treatment as the factor. The same analysis also was utilized in body mass and egg volume comparison among treatments. One-way ANCOVA was used to compare the egg number among dietary treatments using female body mass as covariable. The metabolism data were analyzed by a two-way ANCOVA, with diet and ontogenetic stage as main factors and body mass as covariate. All data were analyzed for normality and homoscedasticity. When differences in the means were significant at the $\mathrm{P}<0.05$ level they were also tested with a posteriori Tukey test (HSD) (Sokal \& Rohlf 1997). All statistical analyses were conducted using SPSS 12.0 for windows software. Data are presented as mean \pm standard error (SE).

\section{RESULTS}

\section{Life-history traits}

The duration of the entire life cycle was very similar in the different diet treatments with an average of $206.5 \pm 25.5$ days in HP and 216.0 
\pm 19.6 days in LP diet, and a similar pattern was observed in the control treatments $(\mathrm{F}=$ $1.714, \mathrm{df}=3.160, \mathrm{P}=0.1542$ ) (see Fig. 1 ). The same results were obtained when the duration of pupae stage was considered $(\mathrm{F}=0.926, \mathrm{df}=$ 3.160, $\mathrm{P}=0.2349$ ) (Fig. 1).

Larval growth rate from all four diets were similar from the beginning to the $105^{\text {th }}$ day of the experiment $(\mathrm{F}=0.03, \mathrm{df}=3.47, \mathrm{P}=0.993)$ (Fig. 2A). From the $105^{\text {th }}$ to $175^{\text {th }}$ day of the experiment LGR increased significantly in all treatments compared with rates of previous periods (Repeated measures ANOVA; $\mathrm{F}=15.27$, $\mathrm{df}=2.92, \mathrm{P}=0.0021)$. However, differences among diet treatments were neither observed in the last period $(\mathrm{F}=0.45, \mathrm{df}=3.47, \mathrm{P}=$ 0.4521) (Fig. 2A). In general, for all four treatments AGR was negative, with adults from low diets protein with higher rates of mass loss (Fig. 2B). We did not observe statistical differences in AGR in the two time periods of adult life of the experimental individuals $(\mathrm{F}$ $=1.77, \mathrm{df}=3.169, \mathrm{P}=0.155$ and $\mathrm{F}=1.28, \mathrm{df}=$ $3.69, \mathrm{P}=0.086$ for $205-215$ and $215-225$ life days range, respectively).

Egg size and egg number of female $T$. molitor developed in markedly different ways with respect to food quality. Mean egg number varied from $12 \pm 4.17$ for females on HPC diet, to $5.42 \pm 3.81$ for females on the LPC diet (Table 2). Female body mass was not significantly different between treatments $(\mathrm{F}=1.816, \mathrm{df}=3.36 ; \mathrm{P}=0.215)$ (see Fig. 1$)$. Significant differences were observed in egg number per female between the HP and HPC diet comparing with the other two diets (F $=21.715, \mathrm{df}=3.36, \mathrm{P}=0.0001)$. The effect of rearing diet was significant in egg number and individuals maintained during larval stage in LP diet and switched to HP in pupal stage did not recuperate the egg production capacity as adults. The size of recently released eggs were similar between all treatments $(\mathrm{F}=0.826, \mathrm{df}=$ $3.150, \mathrm{P}=0.358)$ (Table 2).

\section{Energy metabolism}

A significant interaction between protein treatments and ontogenetic stage on $\mathrm{CO}_{2}$ production was found in $T$. molitor (twoway ANCOVA; $\mathrm{F}=8.335, \mathrm{df}=6.69, \mathrm{P}=$ 0.0001 for interaction term). The effect of protein was significant in the larval stage (two-way ANCOVA; $\mathrm{F}=3.249$, df $=3.69, \mathrm{P}$ $=0.0269)$, where the low protein diet had higher $\mathrm{CO}_{2}$ production comparing with HPHPC treatments (see Fig. 3 and Table 3). As expected, pupae stage show significant lower

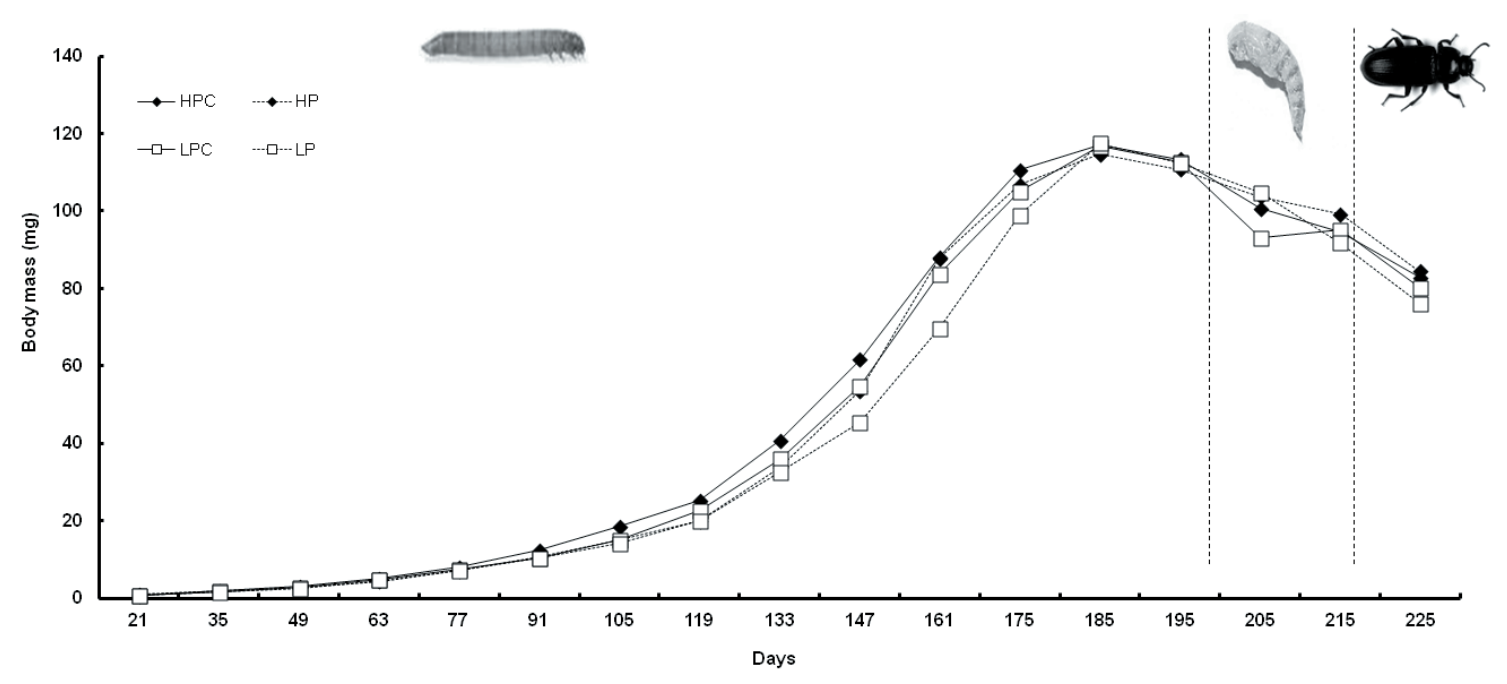

Fig. 1: Body mass of Tenebrio molitor through entire life cycle in different experimental diets. The mean body mass is indicated every 14 days. Abbreviations are; HPC = High Protein Control, HP = High Protein, LPC = Low Protein Control, and LP = Low Protein.

Masa corporal de Tenebrio molitor a través del ciclo de vida completo en las diferentes dietas experimentales. Se indica la masa corporal promedio en intervalos de 14 días. Las abreviaciones utilizadas son: HPC = Control Alta Proteína, HP = Alta Proteína, LPC = Control Baja Proteína, y LP = Baja Proteína. 
values of metabolic rate in all diet treatments with a mean of $0.160 \pm 0.063 \mu 1 \mathrm{~min}^{-1}$ (two-way ANCOVA; $\mathrm{F}=44.298, \mathrm{df}=2.69, \mathrm{P}=0.0001)$, comparing with values of $0.625 \pm 0.137$ and $0.539 \pm 0.050 \mu 1 \mathrm{~min}^{-1}$ for larvae and adult stage, respectively (Fig. 3). Adult and larvae stage from different dietary protein treatments did not show differences in mass-specific $\mathrm{CO}_{2}$ production (Tukey's HSD, $\mathrm{P}>0.05$ ). Insects that were switched from HP to LP as pupae had adult metabolic rates comparable to those insects continuously reared in HP (high protein control) and had the same pattern found in insects switched from LP to HP diet (see Fig. 3). Larval rearing diet did not have effects on adult metabolism (Tukey's HSD, P $>0.05)$.

\section{DISCUSSION}

Food quality describes the chemicals components required by an organism for its optimal growth, tissue maintenance, reproduction and energy expenditure. Food quality affected the life history traits in our study model in contrasting ways. The duration of the complete life-cycle was comparable with what is reported for $T$. molitor standarizing by the different rearing temperatures (see Gerber 1975, Damborsky et al. 1999). Contrary to what it could be expected, the duration of the lifecycle, larval growth rates and body mass in T. molitor were similar among diet treatments despite their contrasting differences in protein concentration. In general, low protein lead
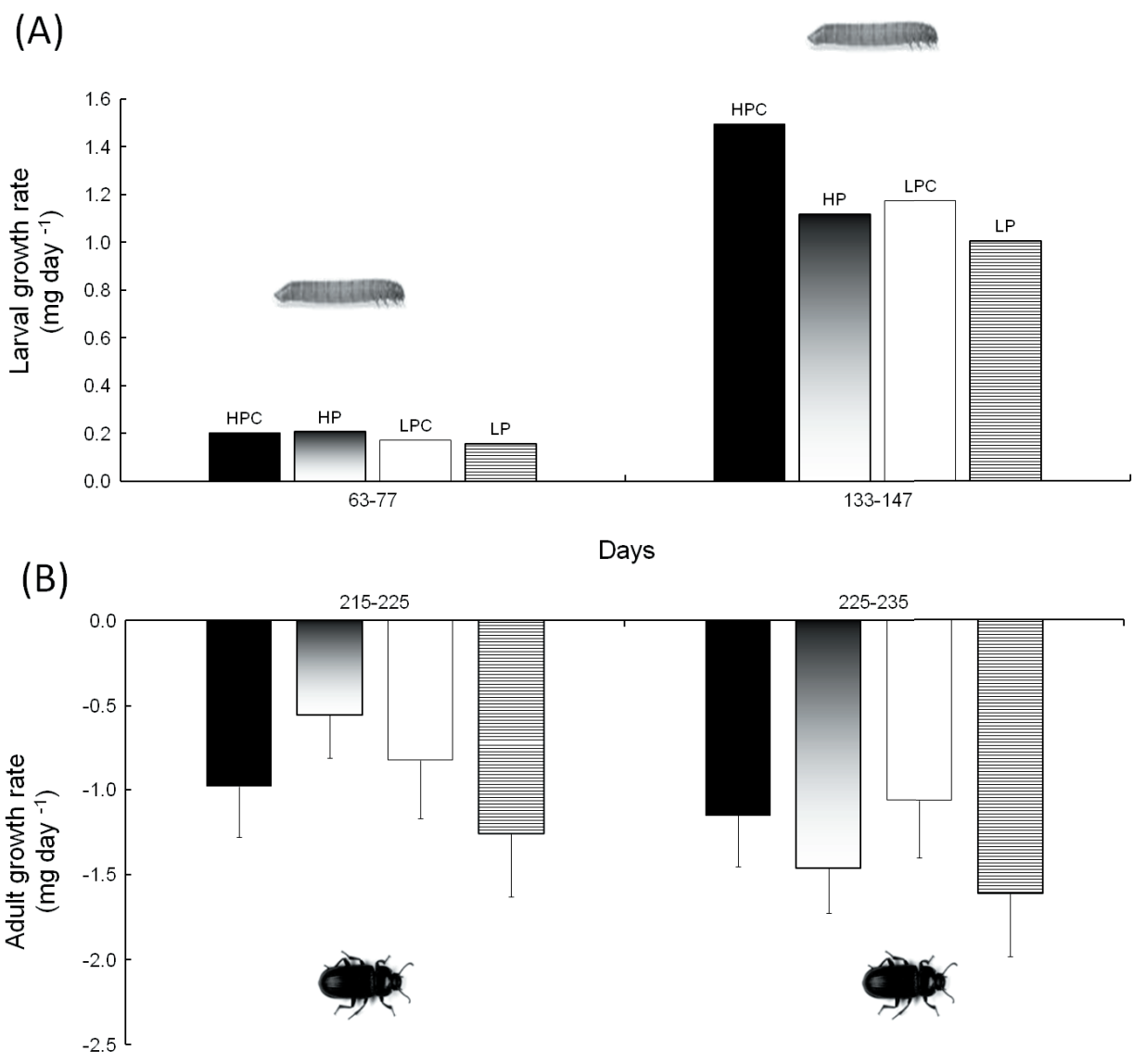

Fig. 2: Effect of dietary protein on (A) larval and (B) adult in growth rate of Tenebrio molitor. The mean is indicated. $(\mathrm{HPC}=$ High Protein Control, HP $=$ High Protein, $\mathrm{LPC}=$ Low Protein Control, $\mathrm{LP}=$ Low Protein $)$. The mean and $\pm \mathrm{SE}$ is indicated in Fig. $2 \mathrm{~B}$. See results for statistics.

Efecto de la proteína en la dieta sobre (A) tasa de crecimiento de la larva y (B) tasa de crecimiento del adulto en Tenebrio molitor. $(\mathrm{HPC}=$ Control Alta Proteína, HP = Alta Proteína, LPC = Control Baja Proteína, LP = Baja Proteína $)$. Se indica la media \pm EE en la Fig. 2B. Ver resultados para la estadística. 
to reduced rates of growth (Scriber 1984, Woods 1999). However, our data shows that experimental diets did not delay the larval and pupae development nor body mass in the different ontogenetic stages. The little variation among treatments in the number of days of the life cycle, body mass, as well as growth rate could be the result of three non exclusive processes. First, growth depends on nutrient ratios, and insects may use behavioral and postingestive mechanisms to compensate for nutrient imbalance (Raubenheimer \& Simpson 1993, 1997). Beetles appear to perform best on diets containing protein and carbohydrate in roughly equal amounts, and beetles may have consumed low-protein food at higher rates to provided nutrients needed (see Woods 1999). However, whether ingestion rate was different between treatments is unknown. Second, the experimental diets were isocaloric therefore $T$. molitor could respond to total energy ingested and not to particular changes in essentials elements like dietary nitrogen, as occurs in several arthropod (see Joern \& Behmer 1997, Blanco et al. 2009). That is, diet quality (especially variation in diet protein as total nitrogen content), does not affect the duration of the life-cycle, and at the same time, neither body mass nor larval growth rate. Third, plasticity is common in early post-embryonic or adult development, but many organisms also exhibit development inflexibility during ontogeny, which is the lack of the ability to change reproductive tactics during phases of the lifecycle (Hatle et al. 2004, Hatle et al. 2005). Our results showed that traits such as duration in days of ontogenetic stages, growth rate in larval and adult stage and egg size and body mass in response to different diet would be canalized in T. molitor. This last affirmation is supported by our results since the diet switches realized in pupal phase did not affect the timing of moulting and metamorphosis nor the adult growth rate.

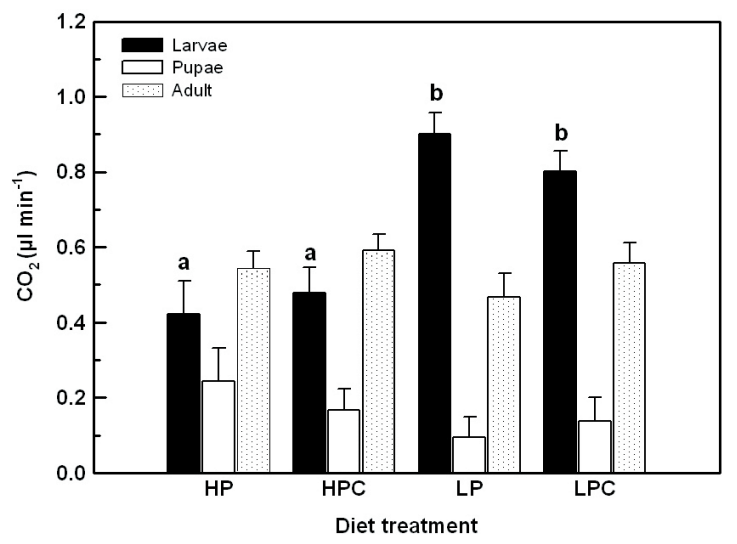

Fig. 3: Metabolic rate of different stages in the complex life cycle $(\mathrm{L}=$ Larvae, $\mathrm{P}=$ Pupae, $\mathrm{A}=$ Adult $)$ of Tenebrio molitor maintained in different protein treatments $(\mathrm{HP}=$ High Protein, HPC $=$ High Protein Control, LP $=$ Low Protein, and LPC = Low Protein Control). The mean and \pm SE is indicated. Significant differences among protein treatments are highlighted by different letters.

Tasa metabólica de los diferentes estadios $(\mathrm{L}=$ Larva, $\mathrm{P}=$ Pupa, A = Adulto) en el ciclo de vida complejo de Tenebrio molitor mantenidos en diferentes tratamientos de proteína $(\mathrm{HP}=$ Alta Proteína, HPC $=$ Control Alta Proteína, $\mathrm{LP}=$ Baja Proteína y LPC $=$ Control Baja Proteína). Se indica la media \pm EE. Las diferencias significativas entre los tratamientos de proteínas son resaltadas por diferentes letras.

TABLE 2

Offspring number/day and size in females of Tenebrio molitor maintained through the entire life cycle on the different protein diets. Values show are mean $\pm(\mathrm{SE}) . \mathrm{N}$ indicates number of females analyzed. A different letter indicates significant differences at the $5 \%$ level.

Número de huevos producidos por día y tamaño de las hembras de Tenebrio molitor mantenidos durante todo el ciclo de vida en los diferentes tratamientos de proteínas. Valores mostrados son media \pm (EE). $\mathrm{N}$ indica el número de hembras analizadas. Las diferencias significativas entre los tratamientos de proteínas son resaltadas por diferentes letras.

\begin{tabular}{lcccc}
\hline & High protein & High protein control & Low protein & Low protein control \\
\hline Egg number/day & $11( \pm 6.28)^{\mathrm{a}}$ & $12( \pm 4.17)^{\mathrm{a}}$ & $6.13( \pm 2,01)^{\mathrm{b}}$ & $5.42( \pm 3.81)^{\mathrm{b}}$ \\
Egg size $(\mathrm{mm})$ & $1.76( \pm 0.13)$ & $1.70( \pm 0.05)$ & $1.73( \pm 0.12)$ & $1.68( \pm 0.21)$ \\
$\mathrm{N}$ & 11 & 6 & 14 & 7 \\
\hline
\end{tabular}


Number and size of eggs are life history traits of key relevance for fitness in nature (Stearns 1992), determining the persistence of populations. Our results showed that egg size did not change among diets, but the clutch size was larger in HP diet compared with the LP diet. A classical trade-off in life-history theory predicts that if parental resources are limited, increasing resource allocation to one offspring means that the other offspring must either be smaller or fewer in number. These trade-offs between offspring size and number have received a great deal of theoretical and empirical support (Holloway et al. 1987, Bernardo 1996, Fox \& Czesak 2000, Vijendravarma et al. 2009). In our study, egg number was affected with no evidence of a trade-off between number of eggs and their size, resulting in the observation that the quality of the diet ingested during early ontogeny can be the main cause of changes in some trait values. Several authors are agreed that, especially for herbivores arthropod, mothers in environments of rich or poorresource produce eggs of similar size (Geister et al. 2008), being a non-plastic (fixed) trait probably due to the fact that egg size is directly related to the fitness of individual offspring in many arthropods (Capinera 1979). Similar observations have been reported for ants, butterflies, flies, grasshoppers, isopods and among other arthropods (Joern \& Behmer 1997, Aron et al. 2001, Romeis \& Wäckers 2002, Wall et al. 2002, Lardies et al. 2004, Kyneb \& Toft 2006). Dietary restriction in Drosophila results in a situation that is characterized by reduced fecundity and increased starvation resistance (Piper et al. 2005). Interestingly, the switch of individuals in pupal stage from LP diet to HP diets showed the same result as the control (LPC), that is to say, the egg number of females is determined by diet ingested in larval stage no matter if adult are fed with HP or LP diet. A more complete explanation for this change in fecundity is that this trait can be switched on or off as a consequence, or as a response to, environmental challenge (Spicer \& Gaston 1999). In other words, an early stimulus or environmental challenge, that operates at a critical or sensitive period (larval phase) can result in a long-term change in the structure or traits of an organism, in this case female egg number. This phase may exist because there are physiological limitations on how rapidly an organism can respond developmentally to environmental challenges (Schlichting \& Pigliucci 1998). The last assertion is supported in T. molitor because the duration of the adult

TABLE 3

Rate of $\mathrm{CO}_{2}$ emission and mass-specific metabolic rate of Tenebrio molitor in different ontogenetic stages at $20{ }^{\circ} \mathrm{C}$. Data for the treatments $(\mathrm{HP}=$ High Protein and $\mathrm{LP}=$ Low Protein) and their respective controls (CHP and CLP) were combined. Values show are mean \pm (SE).

Tasa de producción de $\mathrm{CO}_{2}$ y metabolismo masa-específico de Tenebrio molitor en diferentes estadíos ontogenéticos a $20{ }^{\circ} \mathrm{C}$. Los datos para los tratamientos (HP = Alta Proteína y LP = Baja Proteína) y sus respectivos controles (CHP y CLP) fueron combinados. Los valores mostrados corresponden al promedio \pm (EE).

\begin{tabular}{|c|c|c|c|c|c|}
\hline & & & Body mass & $\begin{array}{l}\text { Rate of } \mathrm{CO}_{2} \\
\text { emission }\end{array}$ & $\begin{array}{l}\text { Mass-specific } \\
\text { metabolic rate }\end{array}$ \\
\hline Treatment & Stage & $\mathrm{N}$ & $(\mathrm{g})$ & $\mathrm{ml} \mathrm{CO}_{2} \mathrm{~h}^{-1}$ & $\mathrm{ml} \mathrm{CO} \mathrm{h}^{-1} \mathrm{~g}^{-1}$ \\
\hline \multirow[t]{3}{*}{ Low protein } & Larvae & 13 & $0.0148 \pm 0.0047$ & $0.0414 \pm 0.0032$ & $2.690 \pm 0.34$ \\
\hline & Pupae & 14 & $0.1133 \pm 0.0072$ & $0.0086 \pm 0.0047$ & $0.078 \pm 0.02$ \\
\hline & Adult & 14 & $0.1084 \pm 0.0073$ & $0.0307 \pm 0.0053$ & $0.273 \pm 0.05$ \\
\hline \multirow{3}{*}{$\begin{array}{l}\text { High } \\
\text { protein }\end{array}$} & Larvae & 8 & $0.0161 \pm 0.0077$ & $0.0271 \pm 0.0047$ & $1.438 \pm 0.12$ \\
\hline & Pupae & 10 & $0.1126 \pm 0.0094$ & $0.0117 \pm 0.0044$ & $0.107 \pm 0.02$ \\
\hline & Adult & 23 & $0.1071 \pm 0.0060$ & $0.0340 \pm 0.0024$ & $0.294 \pm 0.07$ \\
\hline
\end{tabular}


period (about 25 days) is shorter than the larval stage (about 165 days). A trade-off between female fecundity and subsequent offspring fitness can be an important selective factor in the evolution of fecundity (McGinley \& Charnov 1988, Lardies et al. 2004).

It could be argued that nutrient limitation (i.e. protein) was not enough to affect the life-cycle and life history traits of $T$. molitor. However, the experimental high protein diet used by us were the ones described by Martin \& Hare (1942) which includes the optimum growth rates for larvae and feundity for females. Life-cycle characteristics (i.e. duration of stages, body mass and growth rate) support the idea that these traits are unaffected by diet quality. On the other hand, female egg numbers support the hypothesis "effect of rearing diet" (see Woods 1999). This outcome may arise if long-term exposure to a particular concentration of protein affects the capacity for egg production but not for short-term compensation in adult stage (for an example see Simpson et al. 1990). This fact would reflect that dietary protein has long-term postive effects in fecundity. Despite that quantification of hexameric storage of proteins was not realized in this study our resuls implies that the amount of storage of proteins during larval stage could be the threshold for egg number in T. molitor.

In terms of energy metabolism, we found that this variable is affected by diet in larval stage showing that the larvae reared in low protein environment have higher metabolic rate and this effect is not transferred to adult phase. Larvae fed on a protein-deficient diet exhibited significantly higher respiratory rates on a $\mu 1 \mathrm{~min}^{-1}$ basis than larvae fed on a rich protein diet. A similar observation have been reported in blowflies reared in different protein environments and where respiratory rate was directly correlated with the occurrence of a protein hunger drive (Calabrese \& Stoffolano 1974).

In general our data are consistent with the view that herbivorous insects balance their nutrient budget. One means to stabilize nutrient intake, and thus growth and developmental performance, is through compensatory feeding (see Berner et al. 2005). Results showed that beetles differentially utilized ingested protein and carbohydrate and consequently achieved similar growth on all four diets despite having ingested very different amounts of protein and carbohydrate. Compensatory feeding could act in T. molitor larvae indicating differences in metabolism but not in growth rate, body mass and life-cycle characteristics. It is unknown if the ingestion rate, as mentioned ealier, is higher in larvae reared on a low protein diet, however the previous implies a higher ingestion of carbohydrate. A possible explanation accounting for differences in metabolism lies in the fact that compensatory feeding implies a trade off in that one nutrient is always ingested in excess of the physiological requirements unless the nutrients are perfectly balanced (Zanotto et al. 1993, 1997, Simpson et al. 2004). The previous implies a mechanism where the diet-induced thermogenesis, that occur in most if not all organisms (including insects) and functions to maintain nutritional homeostasis by metabolically oxidizing excess of energy intake, to maintain a metabolic pool of nutrients that is balanced in both energy and nutrients (Trier \& Mattson 2003).

It has been suggested that physiological traits are set, often referred to as being 'programmed', by the nutritional environment experienced during early growth (Lardies et al. 2004). Such changes in physiological processes may serve to 'match' individual phenotypes to the environment that they are most likely to encounter as adults (Monaghan 2008). Contrary to expectation no differences in metabolic rates were detected in adult beetles, nevertheless, differences were detected in other traits such as fecundity. The female cost in fecundity would be triggered in early ontogeny (i.e. high metabolic rate) which is not reversible as demonstrated by beetles that were switched from low protein to high protein diet as pupae. There is no effect in metabolism of the rearing diet and neither in the test diet in adult stage. Beetles that ate a high-protein diet had lower metabolic rates than those that ate a low-protein diet as larvae, but the rearing diet had not effect in the posterior effects. This outcome suggests that either the physiology of late instars is not affected by dietary conditions in early instars or that later stages are less able to compensate for low-quality diets (see Woods 1999). An explanation could be the large time required for this acclimation is sufficient in the larvae stage compared with the small period of life as an adult. Metabolic rate affects developmental time 
in insects which is dependent on moult number and time interval between moult (Donahaye 1990, Greenberg \& Amos 1996). Interestingly, differences in metabolic rate did not affect developmental time in larvae of $T$. molitor which implies a trade-off with other organismal functions or some traits. Insect pupae grow rapidly and derive energy and materials used in development from fixed internal stores (Odell 1998), while exchanging only oxygen, carbon dioxide, water, and heat with the environment. Tenebrio molitor pupae showed the lower metabolic rate in all diet treatments, a pattern found in other insects (Harak et al. 1996). In our study the metabolic rate increased rapidly in adult stage without the differences that were present in larval stage. An explanation to the previous pattern is that insects begin metamorphosis as a large, complex organism that breaks down certain tissues and reforms others form new structures and may reset most metabolic functions (Collatz 2003).

ACKNOWLEDGEMENTS: Financial support was provided by a FONDECYT 1080123 project. The authors wish to thank Pablo Cortez for his help with metabolic measurements. We are very grateful for the constructive comments of two anonymous reviewers. Roberto Nespolo acknowledge FONDECYT grant No 1090423. All experiments were conducted according to current Chilean law.

\section{LITERATURE CITED}

ALONSO C \& CM HERRERA (2000) Seasonal variation in leaf characteristics and food selection by larval noctuids on an evergreen Mediterranean shrub. Acta Oecologica 21: 257-265.

ARON S, L KELLER \& L PASSERA (2001) Role of resource availability on sex, caste, and reproductive allocation ratios in the Argentine ant Linepithema humile. Journal of Animal Ecology 70: 831-839.

AWMACK CS \& SR LEATHER (2002) Host plant quality and fecundity in herbivorous insects. Annual Review of Entomology 47: 817-844.

BERNARDO J (1996) The particular maternal effect of propagule size, especially egg size: Pattern models, quality of evidence and interpretations. American Zoologist 36: 216-236

BERNER D, WU BLANCKENHORN \& C KORNER (2005) Grasshoppers cope with low host plant quality by compensatory feeding and food selection: $\mathrm{N}$ limitation challenged. Oikos 111: 525-533.

BHATTACHARYA AK, JJ AMEEL \& GP WALDBAUER (1970) A method for sexing living pupal and adult yellow mealworms. Annals of the Entomological Society of America 63: 1783.

BLANCO CA, M PORTILLA, CA ABEL, H WINTERS,
R FORD \& D STREET (2009) Soybean flour and wheat germ proportions in insect artificial diet and their effect on the growth rates of Heliothis virescens (F.) (Lepidoptera: Noctunidae). Journal of Insect Science 9: 1-29.

BOGGS CL (2009) Understanding insect life histories and senescence through a resource allocation lens. Functional Ecology 23: 27-37.

BOUVET JM, P VIGNERON \& A SAYA (2005) Phenotypic plasticity of growth trajectory and ontogenic allometry in response to density for Eucalyptus hybrid clones and families. Annals of Botany 96: 811-821.

CALABRESE EJ \& JG JR STOFFOLANO (1974) The influence of age and diet on respiration in adult male and female blowflies, Phormia regina. Journal of Insect Physiology 20: 383-393.

CAPINERA JL (1979) Qualitative variation in plants and insects: Effect of propagule size on ecological plasticity. American Naturalist 114: 350-361.

CASTAÑEDA LE, CC FIGUEROA, LD BACIGALUPE \& RF NESPOLO (2010a) Effects of wing polyphenism, aphid genotype and host plant chemistry on energy metabolism of the grain aphid, Sitobion avenae. Journal of Insect Physiology 56: 1920-1924.

CASTAÑEDA LE, CC FIGUEROA \& RF NESPOLO (2010b) Do insect pests perform better on highly defended plants? Costs and benefits of induced detoxification defences in the aphid Sitobion avenae. Journal of Evolutionary Biology 23: 24742483.

CASTAÑEDA LE, P SABAT, SP GONZALEZ \& RF NESPOLO (2006) Digestive plasticity in tadpoles of the Chilean giant frog (Caudiverbera caudiverbera): Factorial effects of diet and temperature. Physiological and Biochemical Zoology 79: 919-926.

CHOWN SL \& SW NICOLSON (2004) Insect physiological ecology. Mechanisms and patterns. Oxford University Press, Oxford.

CODY ML (1966) A general theory of clutch size. Evolution 20: 174-184.

COLLATZ KG (2003) Aging and environmental conditions in insects. In: Osiewacz HD (ed) Aging of organisms: 99-123. Kluwer Academic Publishers, The Netherland.

COTTON RT (1927) Notes on the biology of the mealworms Tenebrio molitor L. and T. obscurus Fab. Annals of the Entomological American Society 20: $81-86$.

DAMBORSKY M, T SANDRIGO-YBRAN, ME BAR \& E OSCHEROV (1999) Ciclo de vida de Tenebrio molitor en condiciones experimentales. Comunicaciones Cientificas y Tecnologicas UNNE (Argentina) 6: 35-38.

DE JONG G \& AJ VAN NOORDWIJK (1992) Acquisition and allocation of resources: Genetic (co) variances, selection and life histories. American Naturalist 139: 760-761.

DE WITT TJ, A SIH \& DS WILSON (1998) Costs and limits of phenotypic plasticity. Trends in Ecology and Evolution 13: 77-81.

DIGGLE PK (2002) A developmental morphologist's perspective on plasticity. Evolutionary Ecology 16: 267-283.

DONAHAYE E (1990) Laboratory selection for resistance by the red flour beetle Tribolium castaneum (Herbst.) to an atmosphere of low oxygen concentration. Phytoparasitica 18: 189-202. 
FAO (1992) International Plant Protection Convention (IPPC) (AGPP/PQ/92/1). Food and Agriculture Organization of the United Nations, Rome.

FOX CW \& ME CZESAK (2000) Evolutionary ecology of progeny size in arthropods. Annual Review of Entomology 45: 341-369.

GEISTER TL, MW LORENZ, KH HOFMANN \& K FISCHER (2008) Adult nutrition and butterfly fitness: Effects of diet quality on reproductive output, egg composition, and egg hatching success. Frontiers Zoology 5: 10.

GERBER GH (1975) Reproductive behaviour and physiology of Tenebrio molitor (Coleoptera: Tenebrionidae). II. Egg development and oviposition in young females and the effects of mating. Canadian Entomology 107: 551-559.

GREENBERG S \& A AMOS (1996) Effects of chronic hypoxia, normoxia and hyperoxia on larval development in the beetle Tenebrio molitor. Journal of Insect Physiology 42: 991-996.

GREENE E (1989) A diet-induced developmental polymorphism in a caterpillar. Science 243: 643646.

HARAK M, I LAMBRECHT \& A KUUSIK (1996) Metabolic cost of ventilating movements in pupae of Tenebrio molitor and Galleria mellonella studied by direct calorimetry. Thermochimica Acta 276: $41-47$.

HATLE JD, JRT WASKEY \& SA JULIANO (2005) Plasticity of grasshopper vitellogenin production in response to diet is primarily a result of changes in fat body mass. Journal of Comparative Physiology B 176: 27-34.

HATLE JD, AL ANDREWS, MC CROWLEY \& SA JULIANO (2004) Interpopulation variation in developmental titers of vitellogenin, but not storage protein, in lubber grasshoppers. Physiological and Biochemical Zoology 77: 631640.

HOFFMANN EA \& DW PFENNIG (1999) Proximate causes of cannibalistic polyphenism in larval tiger salamanders. Ecology 80: 1076-1080.

HOLLOWAY GJ, RH SMITH, AE WRELTON, LL LI, \& GT MENÉNDEZ (1987) Egg size and reproductive strategies in insects infesting storedproducts. Functional Ecology 1: 229-235.

HOVERMAN JT \& RA RELYEA (2007) The rules of engagement: How to defend against combinations of predators. Oecologia 154: 551-560.

HOWARD RS (1955) The biology of the grain beetle Tenebrio molitor with particular reference to its behavior. Ecology 26: 262-269.

JOERN A \& ST BEHMER (1997) Importance of dietary nitrogen and carbohydrates to survival, growth and reproduction in adults of the grasshopper Ageneotettix deorum (Orthoptera: Acrididae). Oecologia 112: 201-208.

KAROWE DN \& MM MARTIN (1989) The effects of quantity and quality of diet nitrogen on the growth, efficiency of food utilization, nitrogen budget, and metabolic rate of fifthinstar Spodoptera eridania larvae (Lepidoptera: Noctuidae). Journal of Insect Physiology 35: 699708.

KOZLOWSKI J (1992) Optimal allocation of resources to growth and reproduction: Implications for age and size at maturity. Trends in Ecology and Evolution 7: 15-19.

KYNEB A \& S TOFT (2006) Effects of maternal diet quality on offspring performance in the rove beetle Tachyporus hypnorum. Ecological Entomology 31: 322-330.

LARDIES MA, MJ CARTER \& F BOZINOVIC (2004) Dietary effects on life history traits in a terrestrial isopods: The importance of evaluating maternal effects and trade-offs. Oecologia 138: 387-395.

LEROI AM, AF BENNETT \& RE LENSKI (1994) Temperature acclimation and competitive fitness: An experimental test of the beneficial acclimation assumption. Proceedings of the National Academy of Sciences USA 91: 1917-1921.

MARTIN HE \& L HARE (1942) The nutritive requirements of Tenebrio molitor larvae. Biological Bulletin 83: 428-437.

MCGINLEY MA \& EL CHARNOV (1988) Multiple resources and the optimal balance between size and number of offspring. Evolutionary Ecology 2: $77-84$

MONAGHAN P (2008) Early growth conditions, phenotypic development and environmental change. Philosophical Transactions of the Royal Society B 363: 1635-1645.

MORAN NA (1994) Adaptation and constraint in the complex life cycles of animals. Annual Review in Ecology and Systematics 25: 573-600.

NESPOLO RF, LE CASTAÑEDA \& DA ROFF (2007) Quantitative genetic variation of metabolism in the nymphs of sand cricket, Gryllus firmus, inferred from an analysis of inbred lines. Biological Research 40: 5-12.

PIPER MD, W MAIR \& L PARTRIDGE (2005) Counting the calories: The role of specific nutrients in extension of life span by food restriction. Journal of Gerontology 60: 549-555.

PIGLIUCCI M (2007) Do we need an extended evolutionary synthesis? Evolution 61: 2743-2749.

PIGLIUCCI M (2005) Evolution of phenotypic plasticity: Where are we going now? Trends in Ecology and Evolution 20: 481-486.

PIGLIUCCI M (1997) Ontogenetic phenotypic plasticity during the reproductive phase in Arabidopsis thaliana (Brassicaceae). American Journal of Botany 84: 887-887.

PRESTON KA \& DD ACKERLY (2004) Allometry and evolution in modular organisms. In: Pigliucci M \& KA Preston (ed) Modularity and phenotypic complexity: 80-106. Oxford University Press, Oxford.

RAUBENHEIMER D \& SJ SIMPSON (1997) Integrative models of nutrient balancing: Application to insects and vertebrates. Nutrition Research Reviews 10: 151-179.

RAUBENHEIMER D \& SJ SIMPSON (1993) The geometry of compensatory feeding in the locust. Animal Behavior 45: 953-964.

ROGOWITZ GL \& MA CHAPPELL (2000) Energy metabolism of eucalyptus-boring beetles during rest and locomotion: Gender makes a difference. Journal of Experimental Biology 203: 1131-1139.

ROMEIS J \& FL WÄCKERS (2002) Nutritional suitability of individual carbohydrates and amino acids for adult Pieris brassicae. Physiological Entomology 27: 148-156.

ROTEM K, AA AGRAWAL \& L KOTT (2003) Parental effects in Pieris rapae in response to variation in food quality: Adaptive plasticity across generations? Ecological Entomology 28: 211-218.

SCHLICHTING CD \& M PIGLIUCCI (1998) Phenotypic evolution: A reaction norm perspective. Sinauer Associates, Sunderland, MA. 
SCHULTZ JC, PJ NOTHNAGLE \& H BALDWIN (1982) Seasonal and individual variation in leaf quality of two northern hardwoods tree species. American Journal of Botany 69: 753-759.

SCRIBER JM (1984) Host-plant suitability. In: Bell WJ \& RT Carde (eds) Chemical ecology of insects: 159-202. Volume 1. Sinauer Associates, Inc, Sunderland, Massachusetts.

SIMPSON SJ, RM SIBLY, KP LEE, ST BEHMER \& D RAUBENHEIMER (2004) Optimal foraging when regulating intake of multiple nutrients. Animal Behavior 68: 1299-1311.

SIMPSON SJ, MSJ SIMMONDS, WN BLANEY \& JP JONES (1990) Compensatory dietary selection occurs in larval Locusta migratoria but not Spodoptera littoralis after a single deficient meal during ad libitum feeding. Physiological Entomology 15: 235-242.

SOKAL RR \& JF ROHLF (1997) Biometry: The principles and practice of statistics in biological research. Third edition. W. H. Freeman and Company, New York.

SPICER JI \& KJ GASTON (1999) Physiological diversity and its ecological implications. Blackwell Science, Oxford.

STOCKHOFF BA (1993) Ontogenetic change in dietary selection for protein and lipid by gypsy moth larvae. Journal of Insect Physiology 39: 677-686.

STUSEK P, F POHLEVEN \& D CAPL (2000) Detection of wood boring insects by measurement of oxygen consumption. International Biodeterioration and Biodegradation 46: 293-298.

TRIER TM \& WJ MATTSON (2003) Diet-induced thermogenesis in insects: A developing concept in nutritional ecology. Environmental Entomology $32: 1-8$.

VAN EMDEN HF (1969) Plant resistance to Myzus persicae induced by a plant regulator and measured by aphid relative growth rate. Entomologia Experimentalis et Applicata 12: 351-364.

VIA S, R GOMULKIEWICZ, G DE JONG, SM SCHEINER, CD SCHLICHTING\& PH VAN TIENDEREN (1995) Adaptive phenotypic plasticity: Consensus and controversy. Trends in
Ecology and Evolution 10: 212-217.

VIDAL P \& M GUERRERO (2007) Los tenebriónidos de Chile. Ediciones Universidad Católica de Chile, Santiago, Chile.

VIJENDRAVARMA RK, AR KRAAIJEVELD \& HCJ GODFRAY (2009) Experimental evolution shows Drosophila melanogaster resistance to a microsporidian pathogen has fitness costs. Evolution 63: 104-114.

WALL R, VJ WEARMOUTH \& KE SMITH (2002) Reproductive allocation by the blow fly Lucilia sericata in response to protein limitation. Physiological Entomology 27: 267-274.

WILSON RS \& CE FRANKLIN (2002) Testing the beneficial acclimation hypotesis. Trends in Ecology and Evolution 17: 66-70.

WOODS HA (1999) Patterns and mechanisms of growth of fifthinstar Manduca sexta caterpillars following exposure to low- or high-protein food during early instars. Physiological Biochemical Zoology 72: 445-454.

WOODS HA \& JF HARRISON (2001) The beneficial acclimation hypothesis versus acclimation of specific traits: Physiological change in waterstressed Manduca sexta caterpillars. Physiological and Biochemical Zoology 74: 32-44.

WOODS HA \& ME CHAMBERLIN (1999) Effects of dietary protein concentration on L-proline transport by Manduca sexta midgut. Journal of Insect Physiology 45: 735-741.

YANG Y \& A JOERN (1994) Compensatory feeding in response to variable food quality by Melanoplus differentialis. Physiological Entomology 19: 75-82.

ZANOTTO FP, SJ SIMPSON \& D RAUBENHEIMER (1993) The regulation of growth by locusts through post-ingestive compensation for variation in the levels of protein and carbohydrate. Physiological Entomology 18: 425-434.

ZANOTTO FP, SM GOUVEIA, SJ SIMPSON, D RAUBENHEIMER \& PC CALDER (1997) Nutritional homeostasis in locusts: Is there a mechanism for increased energy expenditure during carbohydrate overfeeding? Journal of Experimental Biology 200: 2437-2448. 


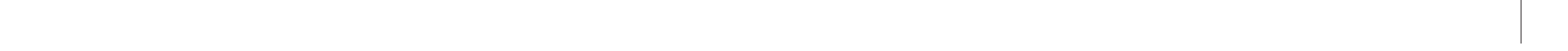

